\title{
PENGEMBANGAN SOFTWARE PEMBELAJARAN BERBASIS VISUAL BASIC PADA MATERI INVERS MATRIKS
}

\author{
Randhi N. Darmawan ${ }^{1)}$, Lailatul Cahyani ${ }^{2)}$ \\ ${ }^{1), 2)}$ Universitas PGRI Banyuwangi \\ Email: rndarmawan@uniba-bwi.ac.id ${ }^{1)}$, lailatulcahyani94@gmail.com ${ }^{2)}$
}

\begin{abstract}
This paper consists of Research and Development that focus on making and building some programs for mathematics education especially discusses invers of matrix. Invers of matrix in Senior High School was introduced in $3^{\text {rd }}$ class and just explained matrix $2 \times 2$ and $3 \times 3$. However, it is not an easy matter/thing to determine invers of matrix $3 \times 3$ because there are some steps that make some students confused and found some difficulties to do it. Therefore, the researcher offers the following steps: First find determinant of matrix, second matrix cofactor and then transpose matrix cofactor become adjoin of matrix, finally multiply adjoin of matrix with determinant. From those steps, sometimes students miss it, so in this paper we will discuss the development of education software (prototype) to compute and determine invers of some matrix. Research and development methodology is applied in this research. The result of the research is merely a trial product for a senior high school and has been proven to be affective and got good feedback as well as respond from the students.
\end{abstract}

Keywords: Research and Development, Software Education, Invers of Matrix.

\section{PENDAHULUAN}

Perkembangan

teknologi informasi dari tahun ke tahun yang semakin cepat menjadi tantangan bagi pengguna teknologi informasi. Kecanggihan teknologi akan terus berkembang dengan pesat diberbagai aspek kehidupan di masa yang akan datang (Syaprina, dkk. 2008). Perkembangan iptek juga mendorong setiap sektor organisasi baik formal maupun informal atau lembaga-lembaga lainnya. Hal ini digunakan untuk penunjang kegiatan kerja sehingga dapat menghasilkan informasi yang cepat, tepat dan akurat. Untuk mewujudkan hal tersebut, dibutuhkan sumber daya pendukung seperti perangkat lunak (software) dan sumber daya manusia yang menguasai teknologi informasi tersebut.

Dalam kehidupan sehari-hari sering dihadapkan dengan persoalanpersoalan matematika. Dengan mengubahnya kedalam bahasa atau persamaan matematika maka persoalan tersebut lebih mudah diselesaikan. Adakalanya suatu persoalan memuat lebih dari dua persamaan dan beberapa variabel, sehingga perlu metodekhusus untuk mencari hubungan antara variabel-variabelnya. Contohnya sering ditemukan model ekonomi yang melibatkan puluhan bahkan ratusan variabel dalam suatu sistem persamaan, 
yang harus ditentukan solusi pemecahannya.

Salah satu metode yang dimanfaatkan untuk memecahkan masalah matematika adalah matriks. Matriks digunakan untuk menemukan solusi persamaan linear (Saefudin, 2014). Matriks dikaitkan dengan penggunaan program linear, analisis input-output baik dalam ekonomi, statistika, maupun dalam bidang pendidikan, manajemen, kimia, dan bidang-bidang teknologi yang lainnya. Matriks juga seperti variabel biasa, sehingga matriks dapat dimanipulasi. Dengan menggunakan matriks akan memudahkan untuk membuat analisisanalisis yang mencakup hubungan variabel-variabel dari suatu persoalan. Antondan Rorres (2010) mendefinisikan matriks sebagai jajaran empat persegi panjang dari bilangan-bilangan. Bilangan bilangan dalam jajaran tersebut disebut entri dari matriks dan merupakan anggota dari bilangan Real.

Materi matriks diajarkan di SMA mapun SMK pada kelas XII yang mana di dalamnya terdapat subpokok bahasan invers matriks yang membahas cara menentukan matriks ordo $2 \times 2$ dan $3 \times 3$, selebihnya diajarkan pada bangku perkuliahan. Invers matriks $2 \times 2$ masih cukup mudah untuk menentukannya, sedangkan pada matriks $3 \times 3$ dibutuhkan beberapa langkah cara yang melibatkan ketelitian siswa dalam menyelesaikannya. Tidak sedikit siswa merasa kesulitan dalam menentukan matriks $3 \times 3$ dan bahkan serasa malas untuk menentukannya, karena sedikit kesalahan perhitungan akan berakibat fatal pada perhitungan seterusnya.

Berdasarkan hal tersebut seiring perkembangan informasi dan teknologi para guru dituntut untuk lebih kreatif dalam metode pembelajarannya disamping itu juga dibutuhkan suatu media pembelajaran yang efektif dan dapat membantu siswa, oleh karena suatu media pembelajaran dalam bentuk software pembelajaran akan sangat membuat para siswa lebih tertarik dan semangat mempelajari dan menentukan invers matriks.

Tambunan (2013) dalam penelitiannya menyatakan bahwa dampak dari penggunaan media pembelajaran diantaranya adalah:

1) menjadikan pembelajaran yang lebih menarik yang dapat memotivasi siswa untuk belajar;

2) materi pembelajaran akan bermakna jelas sehingga siswa mudah mencapai tujuan pembelajaran;

3) untuk menggabungkan beberapa metode pembelajaran;

4) siswa lebih aktif dalam kegiatan pembelajaran.

Mengingat akan pentingnya penggunaan media pemblajaran seperti yang dipaparkan tersebut maka guru atau tenaga pendidik dituntut untuk melakukan pembelajaran yang melibatkan media pembelajaran dalam menyampaikan materi ke peserta didiknya.

Salah satu software pembelajaran yang dapat digunakan dalam pengembangan media pembelajaran adalah visual basic, meskipun bahasa basic terbilang cukup lama dan pada saat ini lebih berkembang bahasa Free Pascal, PHP, dan Java akan tetapi bahasa basic tergolong bahasa pemrograman yang cukup mudah dipahami dan diterapkan dalam perhitungan aritmatik dan logika. Contoh sederhana pada program kasir di Indomaret, Alfamart atau sejenisnya masih menggunakan visual basic dalam melakukan proses operasi aritmatika dan logika. 
Penggunaan media pembelajaran berbasis Visual Basic juga pernah dilakukan oleh Tambunan dalam penelitiannya pada tahun 2013 yang berjudul "Interactive Learning media based Visual Basic and Smoothboard". Penelitian menunjukkan hasil yang baik, yaitu berdasarkan penilaian dari ahli materi adalah sebesar $81,07 \%$ (sangat baik), penilaian dari ahli media adalah sebesar 83,75\% (sangat baik), serta penilaian dari kualitas teknis dan tampilan sebesar 69,37\% (baik).

Riduan dan Buditjahjanto (2015) melakukan penelitian dengan judul "Pengembangan Media Pembelajaran Visual Basic Untuk Mengajar Teknik Pemrograman Di Kelas X Teknik Elektronika SMK Negeri 1 Sidoarjo". Penelitian menunjukkan media pembelajaran berbasis visual basic yang layak digunakan dengan hasil rating 90,20\%. Hasil respon siswa terhadap media pembelajaran dinyatakan sangat baik dengan hasil rating $83,42 \%$. Hasil belajar siswa menghasilkan nilai rata-rata 2,94. Kriteria Ketuntasan Minimum yang digunakan adalah 2,67. Setelah dilakukan uji-t maka diperoleh $t_{\text {hitung }}=5,134$ yang lebih besar dari $t_{\text {tabel }}=1,688$, sehingga sesuai dengan hipotesis awal yang ditetapkan yaitu media pembelajaran berbasis visual basic efektif digunakan dalam mengajar pemrograman di kelas $\mathrm{X}$ teknik elektronika SMK Negeri 1 Sidoarjo.

Studi pendahuluan dilakukan di SMK Darul Anwar Singojuruh kelas X Jurusan Teknik Komputer Jaringan (TKJ). Pada kelas tersebut terdapat materi matriks sebagai mana pada Sekolah Menengah Atas (SMA) dan survey yang dilakukan terhadap siswa dan guru kelas, Ternyata terdapat kesulitan dalam pemahaman siswa terkait materi invers matriks tersebut sehingga dilakukan penelitian untuk mengkombinasikan ilmu komputer yang didapatkan sesuai jurusan siswa dengan konsep matematika yang didapatkan dengan harapan siswa lebih dapat memahami materi invers matriks yang diberikan dan juga lebih bersemangat dalam mempelajari matematika yang merupakan kompetensi dasar bagi seorang yang menekuni dunia komputer media pembelajaran ini dapat dijadikan pedoman dan acuan guru dalam mengajar ke siswa.

Berdasarkan pemaparan di atas maka dapat dirumuskan beberapa tujuan penelitian, yaitu: (1) Menghasilkan media pembelajaran berbasis visual basic pada materi invers matriks yang layak digunakan sebagai media pembelajaran. (2) Menganalisis respon siswa terhadap media pembelajaran visual basic pada materi invers matriks sebagai pertimbangan kelayakan media pembelajaran yang dihasilkan. (3) Mengetahui hasil kerja (tes) siswa menggunakan media pembelajaran berbasis visual basic dalam penyelesaian beberapa soal terkait invers matriks.

\section{METODE PENELITIAN}

Metode penelitian yang digunakan adalah metode penelitian dan pengembangan (R\&D). Dalam Sugiyono (2013: 408), langkahlangkah penelitian pengembangan terdapat 10 (sepuluh) tahapan yaitu: potensi dan masalah, pengumpulan data, desain produk, validasi desain, revisi desain, ujicoba produk, revisi produk, ujicoba pemakaian, revisi produk, dan produksi masal. 
ISSN 2089-8703 (Print) Vol. 6, No. 2 (2017)

ISSN 2442-5419 (Online)

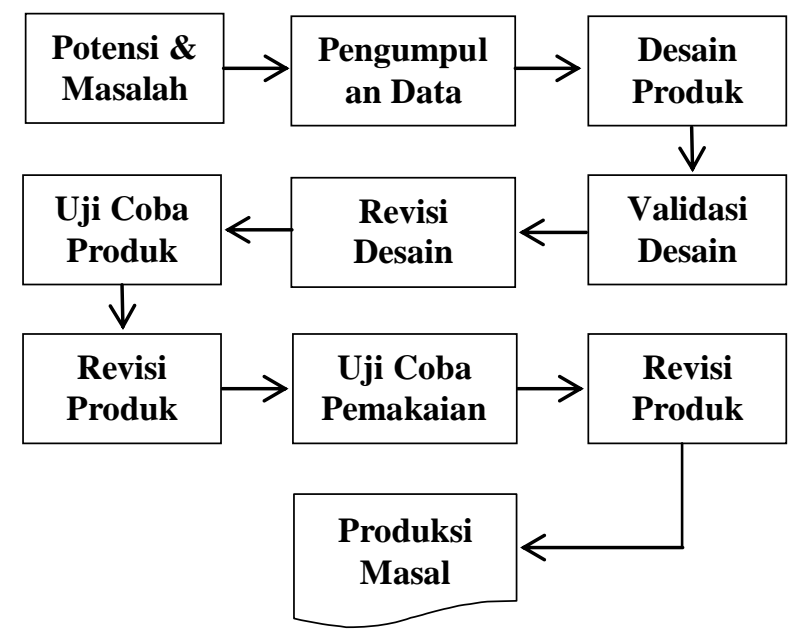

Gambar 1. Skema Langkah Penelitian R\&D (Sugiyono, 2013)

Pada penelitian ini hanya dibatasi sampai uji coba produk dikarenakan keterbatasan waktu dan biaya, akan tetapi untuk kedepannya akan dilakukan penelitian hingga produksi masal. Kemudian dilakukan analisis dan pelaporan dengan tetap mangadaptasi desain penelitian pada Sugiyono (2013:412) seperti pada Gambar 1. Sehingga langkah-langkah yang akan dilakukan dalam penelitian ini adalah sebagai berikut.

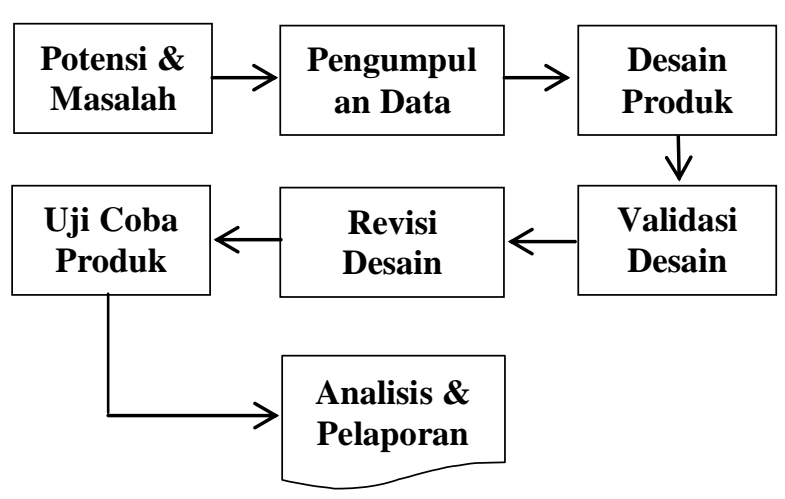

Gambar 2. Skema langkah penelitian yang dilakukan

Instrumen yang digunakan dalam penelitian adalah angket lembar validasi para ahli yang melibatkan tiga validator dengan rincian dua validator

\begin{tabular}{|l|l|}
\hline No. & \multicolumn{1}{|c|}{ Aspek Penelian } \\
\hline Tampilan Media \\
\hline 1. & Pemilihan jenis dan ukuran font \\
\hline 2. & Pemilihan komposisi warna \\
\hline 3. & Tampilan layar \\
\hline 4. & Kejelasan Istilah \\
\hline 5. & Penggunaan Bahasa \\
\hline 6. & Konsistensi urutan penyajian \\
\hline Program \\
\hline 7. & Konsistensi Button \\
\hline 8. & Kemudahan Penggunaan \\
\hline 9. & Efisiensi Penggunaan layar \\
\hline 10. & Kejelasan visual \\
\hline 11. & Efisiensi teks \\
\hline 12. & $\begin{array}{l}\text { Program dapat dibuka dan ditutup } \\
\text { dengan mudah }\end{array}$ \\
\hline 13. & $\begin{array}{l}\text { Kemampuan untuk merespon } \\
\text { penggunaan }\end{array}$ \\
\hline
\end{tabular}




\begin{tabular}{|l|l|}
\hline 14. & \multicolumn{3}{|l|}{ Kecepatan jalannya program } \\
\hline Pembelajaran \\
\hline 15. & $\begin{array}{l}\text { Media pembelajaran relevan } \\
\text { dengan materi yang telah } \\
\text { dipelajari siswa }\end{array}$ \\
\hline 16. & $\begin{array}{l}\text { Isi materi sesuai dengan konsep } \\
\text { yang dikemukakan oleh para ahli }\end{array}$ \\
\hline 17. & Kejelasan uraian materi \\
\hline 18. & Kejelasan istilah \\
\hline 19. & $\begin{array}{l}\text { Kejelasan umpan balik pada } \\
\text { program }\end{array}$ \\
\hline 20. & $\begin{array}{l}\text { Kejelasan umpan } \\
\text { pemahaman siswa }\end{array}$ \\
\hline
\end{tabular}
berikut:

Dengan skala penilaian sebagai

Tabel 2. Kategori Penilaian Skala Likert.

\begin{tabular}{|c|c|c|}
\hline No. & Skor & Keterangan \\
\hline 1. & 4 & Sangat Setuju \\
\hline 2. & 3 & Setuju \\
\hline 3. & 2 & Tidak Setuju \\
\hline 4. & 1 & Sangat Tidak Setuju \\
\hline
\end{tabular}

Uji lembar validasi media pembelajaran berbasis visual basic dengan indikator pada Tabel 1 dan penilaian pada Tabel 2 dapat dilakukan dengan membandingkan jumlah skor yang diberikan oleh validator $\left(\sum R\right)$ dengan jumlah skor ideal yang telah ditetapkan di dalam lembar validasi media pembelajaran $(N)$. Dengan formula sebagai berikut:

$$
P=\frac{\sum R}{N} \times 100 \%
$$

\footnotetext{
Dengan $P$ adalah nilai tingkat persentase pencapaian dengan kualifikasi sebagai berikut:
}

Tabel 3. Tingkat Pencapaian dan Kualifikasi

\begin{tabular}{|c|c|c|l|}
\hline No. & $\boldsymbol{P ( \% )}$ & Kualifikasi & \multicolumn{1}{|c|}{ Ket. } \\
\hline 1. & $75-100$ & SS & $\begin{array}{l}\text { Layak } \\
\text { digunakan } \\
\text { tanpa revisi }\end{array}$ \\
\hline 2. & $50-75$ & S & $\begin{array}{l}\text { Layak } \\
\text { digunakan } \\
\text { dengan } \\
\text { revisi }\end{array}$ \\
\hline 3. & $25-50$ & TS & $\begin{array}{l}\text { Tidak layak } \\
\text { digunakan }\end{array}$ \\
\hline 4. & $0-25$ & STS & $\begin{array}{l}\text { Sangat } \\
\text { tidak layak } \\
\text { digunakan }\end{array}$ \\
\hline
\end{tabular}

Dengan kualifikasi:

$$
\begin{aligned}
\text { SS } & =\text { Sangat Setuju } \\
\text { S } & =\text { Setuju } \\
\text { TS } & =\text { Tidak Setuju } \\
\text { STS } & =\text { Sangat Tidak Setuju }
\end{aligned}
$$

Kemudian dilakukan tes soal yang sesuai dengan materi pada media pembelajaran, yang hasilnya akan dianalisis dengan menggunakan uji statistika yaitu uji-t satu arah (onesample-t-test) untuk mengetahui efektivitas media pembelajaran berbasis visual basic pada materi invers matriks di SMK Darul Anwar Singojuruh Jurusan Teknik Komputer Jaringan (TKJ).

\section{HASIL PENELITIAN DAN PEMBAHASAN}

Penelitian ini menghasilkan produk berupa software media pembelajaran berbasis visual basic pada materi invers matriks. Matriks yang digunakan adalah matriks ordo $2 \times 2$ dan $3 \times 3$ maka tampilan awal program adalah sebagai berikut: 


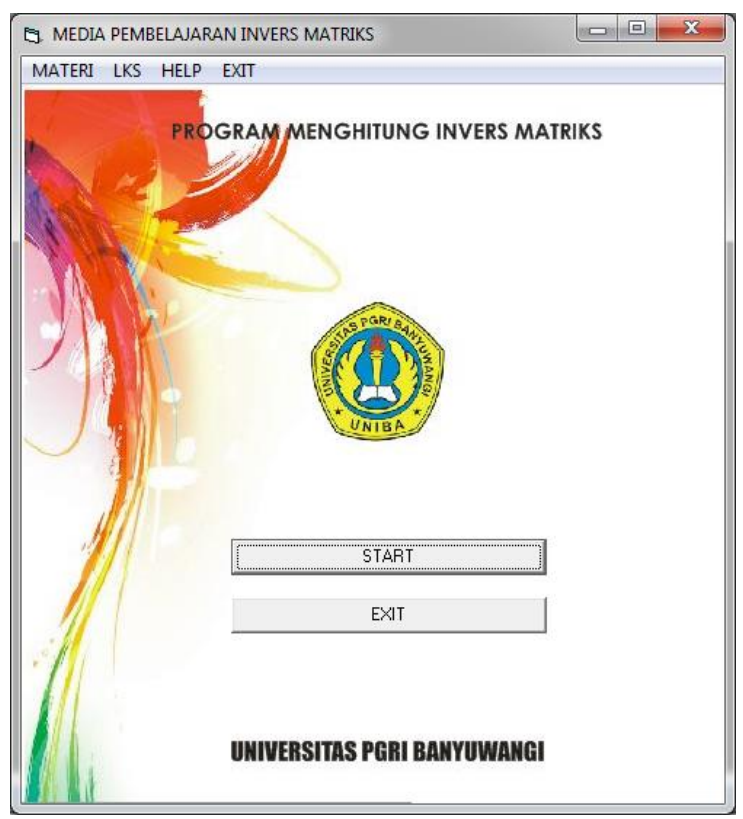

Gambar 3. Tampilan awal program

\section{Pembahasan Validasi oleh Para Ahli}

Berdasarkan validasi program dari tiga validator didapatkan skor sebagai berikut:

Tabel 4. Persentase Skor Validasi

\begin{tabular}{|c|l|c|}
\hline No. & Validator & Skor $(\%)$ \\
\hline 1. & Validator I & $68,75 \%$ \\
\hline 2. & Validator II & $62,5 \%$ \\
\hline 3. & Validator III & $85 \%$ \\
\hline \multicolumn{2}{|c|}{ Rata-rata } & $\mathbf{7 2 , 0 8 \%}$ \\
\hline
\end{tabular}

Berdasarkan hasil pada Tabel 4 bahwa validator I dan II yang memvalidasi program masing-masing memberikan $68,75 \%$ dan $62,5 \%$ yang berarti media pembelajaran layak digunakan dengan revisi dan penyempurnaan. Adapun revisi yang diberikan oleh validator I dan II adalah:
a. Konsistensi penggunaan Command Button pada setiap form.

b. Desain warna terlalu gelap sehingga diganti dengan yang lebih cerah. c. Pengaturan Set. Focus pada masing-masing form perlu diperbaiki.

d. Perlu ditambahkan Message Box untuk mengingatkan siswa jika terjadi salah input pada program.

Sedangkan validator III yang memvalidasi materi yang ada dalam media pembelajaran memebrikan nilai $85 \%$ yang berarti materi yang terkandung dalam media pembelajaran layak digunakan tanpa revisi. Jadi dapat disimpulkan berdasarkan Tabel 2 hasil dari ketiga validator mendapatkan ratarata persentase skor $72,08 \%$ yang berarti media pembelajaran layak digunakan (uji coba) dengan revisi dan penambahan beberapa komponen masukan dari validator.

\section{Uji Coba Produk pada Siswa}

Hasil revisi dari validator selanjutnya media pembelajaran diuji cobakan di kelas pada siswa Jurusan TKJ SMK Darul Anwar Singojuruh sebanyak 40 siswa dan berlangsung di Laboratorium Komputer TKJ sekolah yang bersangkutan.

Uji coba produk pada siswa juga dilengkapi dengan kritik dan saran dari siswa. Kritik dan saran dijadikan sebagai bahan masukan produk dapat diterima atau tidak sebagai media pembelajaran. Adapun revisi atau masukan dari siswa yaitu antara lain "software sangat membantu, aplikasi sangat membantu dan mempermudah, buat juga materi lain agar mempermudah pelajaran."

Sehingga kesimpulan dari angket lembar ujicoba produk terhadap siswa menghasilkan persentase $88,75 \%$ yaitu setuju dengan produk yang dikembangkan sebagai media pembelajaran yang dapat digunakan dalam pembelajaran di sekolah. 
Untuk mengetahui efektifitas produk dalam menyelesaikan persoalan yang sesuai dengan materi invers matriks maka diberikan test kepada 40 siswa dengan nilai Kriteria Ketuntasan Minimal (KKM) di sekolah adalah 75 maka dengan hipotesis awal $\left(H_{0}\right)$ bahwa tidak ada pengaruh uji coba produk dalam penyelesaian soal invers matriks atau dengan kata lain produk yang dicobakan tidak efektif dalam pembelajaran invers matriks.

Hasil test dari 40 siswa didapatkan rata-rata 89,0625 jika diasumsikan data menyebar secara normal maka dengan uji-t satu arah (one-sample-t-test) didapatkan nilai $t_{\text {hitung }}=12.03 \quad$ sedangkan nilai $t_{\text {tabel }}=1,645$ dengan menggunakan taraf signifikasi ( $\alpha=5 \%)$ maka dapat disimpulkan $H_{0}$ ditolak maka produk yang diuji cobakan berpengaruh terhadap pembelajaran siswa atau dengan kata lain media pembelajaran yang diuji cobakan efektif terhadap siswa SMK Darul Anwar Jurusan TKJ.

\section{Hasil Observasi Kondisi Kelas.}

Berdasarkan observasi dari peneliti lain untuk menilai kesesuaian kegiatan saat uji coba media pembelajaran pada siswa didapatkan skor penilaian sebesar 3,71 atau setara dengan $92,86 \%$ yang berarti hasil observasi tersebut menunjukkan media pembelajaran yang dikembangkan dan diuji cobakan dikategorikan sesuai dengan situasi kelas dan dapat digunakan dalam pembelajaran.

Hasil dari penelitian ini adalah berupa software atau aplikasi yang sudah bereksistensi .exe yang dapat digunakan oleh seluruh komputer yang menggunakan sistem operasi Windows tanpa harus ada program Visual Basic 6.0 di dalamnya. Program invers matriks mempunyai kapasitas hanya $680 \mathrm{~Kb}$ atau kurang dari $1 \mathrm{Mb}$ sehingga akan lebih mudah disimpan dan digunakan oleh guru atau siswa dalam proses pembelajaran. Semakin berkembangnya peranan IT maka pembelajaran berbasis komputer sangat diperlukan sehingga akan ada saat dimana pembelajaran tanpa menggunakan buku.

Program invers matriks yang telah jadi di dalamnya juga terdapat materimateri yang relevan yang telah disesuaikan dengan materi matriks siswa SMK, pada proses penggunaanya siswa akan diarahkan menuju form materi terlebih dahulu yang dibaca dan dipahami selanjutnya simulasi penyelesaian contoh soal dan terakhir adalah soal-soal latihan, dengan demikian siswa tidak akan merasa jenuh dengan model pembelajaran yang cenderung monoton.

Berbanding lurus dengan penelitian-penelitian terdahulu bahwasanya Visual Basic dapat digunakan untuk membangun sebuah program pembelajaran yang efektif dan bermanfaat dalam pemebelajaran seperti yang telah dilakukan oleh Tambunan (2013) dan Riduan dan Buditjahjanto (2015) yang telah membuat program pembelajaran berbasis Visual Basic dan berhasil digunakan untuk meningkatkan prestasi belajar siswa.

\section{KESIMPULAN DAN SARAN}

Berdasarkan hasil analisis data penelitian dan pembahasan yang telah dikemukakan terkait pengembangan software pembelajaran berbasis visual basic pada materi invers matriks, maka dapat disimpulkan beberapa hal sebagai berikut : 
1. Software pembelajaran pendidikan matematika dalam materi invers matrik dapat dibuat dan dikembangkan berbasis Visual Basic 6.0 yang dalam pembuatannya terdapat beberapa komponen form yang meliputi materi invers matrik dan contohcontoh soal penyelesaian beserta simulasinya.

2. Hasil validasi media pembelajaran oleh tiga validator dengan menghasilkan persentase $68,75 \%$ dan $62,5 \%$ yang berarti produk layak digunakan dengan revisi sesuai komentar dan saran, dan $85 \%$ yang berarti produk layak digunakan tanpa revisi dan secara keseluruhan rata-rata skor dari validator adalah 72,08 \% yang berarti layak digunakan dengan revisi sesuai saran dan masukan.

3. Hasil ujicoba produk di SMK menghasilkan persentase $88,75 \%$ yang berarti responden siswa terhadap software pembelajaran sangat setuju. Disamping itu nilai didapatkan nilai $t_{\text {hitung }}=12.037$ sedangkan nilai $t_{\text {tabel }}=1,645$ pada taraf signifikansi $(\alpha=5 \%)$ yang berarti terdapat pengaruh atau media pembalajaran yang diuji cobakan efektif.

Adapun saran untuk penelitian selanjutnya adalah software pembelajaran yang dibuat sebaiknya mencakup seluruh operasi hitung yang ada dalam pokok bahasa matriks, tidak hanya sebatas invers matriks sehingga akan lebih membantu dalam proses pembelajaran siswa, selain itu diharapkan penelitian $\mathrm{R} \& \mathrm{D}$ tidak hanya berhenti pada uji coba produk melainkan sampai produksi masal.

\section{DAFTAR PUSTAKA}

Anton, Howard \& Rorres, Chirs. 2010. Elementary Linear Algebra: Applications Version $10^{\text {th }}$ Edition. John Wiley \& Sons

Riduan, Muhammad dan Buditjahjanto, I Gusti Putu Asto. 2015. Pengembangan Media Pembelajaran Visual Basic Untuk Mengajar Teknik Pemrograman Di Kelas X Teknik Elektronika SMK Negeri 1 Sidoarjo. Jurnal Pendidikan Teknik Elektro. Vol. 2, No. 1, Hal 863-868.

Saefudin, A. A. 2014. Aljabar Matriks. Yogyakarta : Graha Ilmu.

Sugiyono. 2013. Metode Penelitian Pendidikan (Pendekatan Kuantitatif, Kualitatif dan R\&D). Bandung: Alfabeta.

Syaprina, Abdillah, A.L. \& Sopiah, Nyimas. 2008. Sistem Informasi Penjualan dan Perbaikan Komputer. Jurnal Ilmiah MATRIK. Vol. 10, No. 02, Hal 113-124.

Tambunan, Hamonangan, 2013. Interactive Learning media based Visual Basic and Smoothboard. The International Journal's Research Journal o Science \& IT Management.Vol. 02, No. 06, Hal $18-23$. 